\title{
Fansub and Auto-Generated Subtitle: Indication of Translation Popular Culture?
}

\author{
Bayu Budiharjo ${ }^{1}$, Nur Saptaningsih ${ }^{2}$

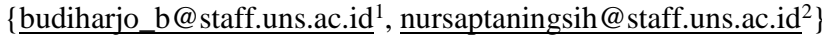 \\ Universitas Sebelas Maret, Surakarta ${ }^{1}$, Universitas Sebelas Maret, Surakarta ${ }^{2}$
}

\begin{abstract}
Subtitling has been a common practice and it develops over time. Subtitle, along with the advancement of technology, enables more people to perform subtitling activities and involves more products of technology. Fan subtitle (fansub) emerges as subtitling softwares can be owned and used by anyone. Automatically-generated subtitle is also nowadays available. The former is characterized by variances as indications of elements of popular culture while the latter deals with contemporary aspects of people's lives and is highly technological. This study attempts to initiate the idea of popular culture within translation. The studied material takes form of subtitle texts in movie uploaded on YouTube entitled Big Stan. Analysis was done to uncover features of the two types of subtitling practices and link them up to features of popular culture. The result reveals that fansub and YouTube auto-generated subtitle show features of popular culture.
\end{abstract}

Keywords: fansub, auto-translated subtitle, YouTube, popular culture.

\section{Introduction}

Subtitling practices have long been carried out in many countries in the world. Over time, subtitling is no longer only done to meet the needs of institutions and television stations and is no longer done by professionals who work for such institutions.

Subtitling developed from what was once (and is until now) the realm of professional to the one entered by dilettantes. Subtitling has long been a realm of fans, which began with the awakening of groups of anime fans known as fansubbers. They "translate, subtitle, and release copies of television shows and films originally broadcast or released in Japan for other fans to watch."[1]

Now it can be done by almost anyone because subtitling software is available free to be downloaded by anyone. This kind of subtitling practice is growing and expanding so that lately it is practiced by many people in various parts of the world. Subtiting done by fans is now covered by internet sites that allow the supporting community to share their work not only with others but also with those who access this kind of sites.

Such practice of subtitling appears to bear a feature of popular culture, which is defined as "the products and forms of expression and identity that are frequently encountered or widely accepted"[2]. 
Subtitling develops and enters the scope of popular culture as technology advances in general and especially translation technology, which also includes subtitling automation. One obvious form of subtitling automation is manifested in many YouTube videos that offer autogenerated subtitle features, in the same language, and auto-translate for those who want subtitles in other languages. This highly technological feature corresponds to the following description of popular culture, which "encompasses the most immediate and contemporary aspects of our lives. These aspects are often subject to rapid change, especially in a highly technological world in which people are brought closer and closer by omnipresent media"[2].

Fansub and YouTube auto-generated subtitle fit the present-day perspective of the sense of popular culture that "the meaning of the term evolved to describe more widely accepted ideas, attitudes and practices transmitted via mass media and aimed particularly at younger people"[3].

As a form of translation that is special in nature, subtitles are governed by various rules and conventions in carrying out their role as a medium to help the audience. A question arises whether the subtitles carried out by fans and automatic devices also comply with the general rules and conventions that govern them.

Fansub and automated subtitling still become areas that have not been much explored in translation research, especially whether the two media can be perceived as popular culture phenomena. This paper attempts to explore the liability of the spark of "translation popular culture" as translation has evolved to a very great degree. Aside from fansub and YouTube auto-generated subtitle, the phenomena also cover, among others, wide use of online Machine Translation and oral translation mobile applications.

There is a solid connection between popular culture and technology. "The link between technology and popular culture was clearly established in the 1920s. In the period before the arrival of television and rock'n'roll, radio and film were the main sources of popular culture. The impact of technology on popular culture became a consistent theme throughout the second half of the 20th century. Ongoing developments in technology also help to explain the ways in which popular culture is able to change and evolve." ${ }^{[3]}$ If radio, film, television and rock'n'roll are sources of popular culture in the life of people, could fansub and YouTube auto-generated subtitle be sources of popular culture in the area of translation? 


\section{Subtitle conventions}

Conventions vary in different regions where a particular subtitling activity is practiced. In this paper, an attempt is made to put prevalent subtitling conventions in a nutshell, particularly those relevant to the investigation carried out in this research..

- Subtitle lines: A maximum of two lines of subtitles should be presented at a time.Subtitles should be positioned at the lower part of the screen, so that they cover an area usually occupied by image action which is of lesser importance to the general aesthetic appreciation of the film. The subtitled text should be presented centered on its allocated line(s) since most of the image action circulates around the centre of the screen.

- Number of characters per line: Each subtitle line should allow around 35 (up to 37) characters in order to be able to accommodate a satisfactory portion of the (translated) spoken text and minimise the need for original text reduction and omissions.

- Segmentation: Subtitled text should appear segmented at the highest syntactic nodes possible. In cases where the sentence cannot fit in a single-line subtitle, the segmentation on each of the lines should be arranged to coincide with the highest syntactic node possible.

- Omission: A decision as to which pieces of information to omit or to include should depend on the relative contribution of these pieces of information to the comprehension and appreciation of the target film as a whole. The subtitler should not attempt to transfer everything, even when this is spatio-temporally feasible.

- Taboo words: Taboo words should not be censored unless their frequent repetition dictates their reduction for reasons of text economy.

- Symbols: Use symbols commonly used and immediately recognised on printed materials. ${ }^{[4]}[5]$

\section{Fansub and popular culture}

Fansub stands for fan-subtitle, which is the label attached to fan-made subtitles to a video or film. Fansubbing started during the 1980 s to make anime (Japanese animation series) accessible to those individuals intrigued by the series but couldn't comprehend Japanese. The development of fansub trend can be credited to the worldwide expanse of anime pop culture ${ }^{[6]}$. Fansub groups usually do not benefit financially from the practices they do, producing subtitle outside professional field.

Fansub is a product of popular culture, the culture that has a feature of providing "a sense of belonging through becoming involved either in a passive way, by simply consuming some of the programmes readily available (e.g. watching a television series with free subtitles), or in an active manner, by engaging with some of the virtual communities and producing some of the material, like the subtitles for the said television series or a new soundtrack with different dialogue exchanges." $"[7]$. 
By offering translations of video texts, non-professional subtitlers, including fansubbers, have become actors in the conveyance of contents and created the links between different countries, cultures or language. They have given significant contribution to the development of media consumption because they enable viewers to enjoy videos without worrying about issues in language comprehension.

\section{YouTube auto-generated subtitle and popular culture}

Similar to fansub, YouTube is part of popular culture as suggested in several studies. Lashley ${ }^{[8]}$, putting remarks on Burgess \& Green's 2009 survey, stated that the study reveals YouTube as a potentially befuddling site of popular culture. A study by Kavoori ${ }^{[9]}$ found that "the most commonly occurring videos (especially those that are most viewed, most favorited, most responded, most discussed) could be most broadly categorized as dealing with 'youth/popular culture.' Even the most casual user of YouTube will recognize that many videos reflect popular culture elements of interest to young people."

In serving as a medium of communication, YouTube is supported by "Auto Translate" feature. This feature of YouTube can automatically add subtitles on some videos, in which the default setting can be changed, either on user's computer or mobile device ${ }^{[10]}$. One technology inside Youtube enables speech recognition to automatically create subtitles attached to videos. In addition, a feature of auto-generated translation is also available. ${ }^{[1]}$. Dealing with making subtitle available for users to obtain, YouTube invites users to actively participate in the creation and circulation of new content ${ }^{[12]}[13]$. This is done through the feature "suggest translation" and can be viewed as a form of participatory culture.

\section{Methodology}

This research aims to open up the prospect to view certain present-day translation activities as a slice of the so-called popular culture. A hardsubbed movie entitled Big Stan, which is available on YouTube was selected and studied to obtain the required information. This video is studied because it provides both fansub, as indicated by the following ID "Subtitle By: Robin808, Retranslate By: Bram Yudha Hertanto", and auto-generated subtitle in bahasa Indonesia. The elements reflecting features of popular culture identified in the fansub and auto-generated subtitle were analyzed. The analysis also involved external factors surrounding these practices. The elements were linked to relevant literatures, particularly those putting remarks on characteristics of popular culture. Final remark was then drawn from the analysis.

\section{Result and discussion}


Detailed examination of the source of data reveals that both types of subtitle, serving as media to provide support to viewers, have some points of difference in playing their role. Each one communicates message in its own "style" based on the different characteristics and features.

A number of detailed variances are identified in how the translated movie content is presented to the viewers. Further account of the variances is discussed in the subsequent sections.

\subsection{Fansub}

1. number of lines. Two-line subtitle is displayed in most scenes in the movie but some scenes are accompanied by subtitle with the third line.

aku beritahu kamu,

Aku tidak mempraktekkan hukum yang seperti itu, dan tidak akan pernah.

Aku yakin "shyster" di jalanan

dengan senang hati akan melakukannya untukmu

(seseorang yang tidak etis, tidak bermoral)

In the second example, the occurrence of the extra -in a negative sense- line is the result of additional information put on the subtitle.

2. number of characters. Two-line subtitle is displayed in most scenes, most of which consist of fewer than 37 characters. Some scenes contain lines with characters exceeding 37 in number. An example of line with exceeding number of character is "Apa ada sesuatu yang lainnya yang bisa aku lakukan?" The line is made up of 53 characters.

3. use of mixed language One of the examples is the use of English vocabulary "jury" in the court scene "Kami sebagai jury, memutuskan terdakwa bersalah." In one of the scenes, the use of foreign language "weladaalah" 1.08.-- is identified, in which the word has Javanese, one of the local languages in the target culture, origin. In another scene, the use of English "music" is also identified.

4. taboo. Dictions which are generally considered taboo in the target language culture, such as "motherfucker" are preserved as taboo expressions in the subtitle."Ini berarti kau adalah salah satu bajingan yang jahat." However, as this research concerns Indonesia culture as the target language culture, such rendering of message contradicts to the prevailing norms.

5. arbitrariness. Arbitrary use of equivalent occurs in different parts of the subtitle. Number sign (\#) is arbitrarily used as the indicator of translation of song lyrics. Number is also differently presented in one line "empat belas, 15". In addition, pronoun "you" is also an item rendered in the target language using different equivalents.

\subsection{YouTube Auto-Translated Subtitle}


1. move (line to line): Unlike subtitle in general, YouTube auto-translated translation displays new line below the previous line.

2. number of characters: Two-line subtitle is displayed in the whole scenes, most of which consist of fewer than 37 characters. Some scenes contain lines with characters exceeding 37 in number.

"timeshare Anda tidak akan merasa aman di sana tidak, saya tidak akan tentu saja Anda tidak akan"

3. absence of dialogue marker. Lines showing dialogues between different characters are not given mark. The translation of utterances within dialogues is displayed as single line. An example of dialogue with no dialogue marker is

"Stanley, aku tidak kehilangan, kau pengacara yang hilang. Aku benar-benar menyesal." The line is in fact a dialogue between two characters consisting of three turns, which should be split into:

Stanley,

aku tidak kehilangan, kau pengacara yang hilang.

Aku benar-benar menyesal.

4. missing words Some words in the movie script are not translated, in the sense that no equivalence can be found in the auto-generated subtitle. One example is found within the scene in which the main character The translation of his expression of surprise "What?" is not present.

5. use of mixed language The use of foreign dictions is also identified, for example "[Music]" and "cougar" are mixed with bahasa Indonesia.

6. sentence chunking Translation is displayed per line instead of per chunk of meaning.

tidak di negara bagian ini penipuan tingkat pertama membawa minimal wajib tiga lima tahun saya mendapatkannya,...

7. position change The lines of the translation automatically generated within the video shift whenever ads are displayed.

8. retention of taboo In some parts of the video, words included in taboo expressions are presented to the viewers in the form of their taboo equivalents. Two of the words regarded as taboo "dick" and "motherfucker" are translated as "off-limits" without any effort to make them more polite in the target language.

The aforementioned findings can be associated with the account put forward by Delaney ${ }^{[2]}$, "popular culture, unlike folk or high culture, provides individuals with a chance to change the prevailing sentiments and norms of behavior." We propose these variances as indications of the presence of elements of popular culture as they put contrast between the phenomenon in the studied movie subtitles and the dominant culture, in which subtitling products need to conform to the governing conventions. Fansub reflects the chance to change 
the prevailing sentiments and norms within the practice of subtitling. We also refer to the statement put forward by Angelaki ${ }^{[14]}$ that "popular culture is always defined by means of contrast to other categories: folk culture, mass culture, dominant culture, working-class culture, etc." Another indication is that by fansub, people are brought far closer to the omnipresent media as subtitles of countless number of movies can be obtained from websites like subscene.com, moviesubtitles.org, and subtitles.hr. In addition, this phenomenon of fanmade (and fan-used) subtitle is not a minor one as it involves large number of people. Subtitle of popular movies can reach thousands to tens of thousands of download by internet users. Therefore, it is justified to view that fansub possesses one of the characteristics of popular culture, in which the culture includes "wide range of activities that a large number of people in a society engage in."[3]

As variances identified in YouTube auto-generated subtitle result from automated engine instead of individuals, changing the prevailing sentiments and norms is not to be attributed to popular culture. However, a line can be drawn linking this feature of YouTube to Delaney's ${ }^{[2]}$ point cited at the beginning of the paper. Popular culture covers contemporary aspects of our lives and involves highly technological world and these features are found to be inherent in YouTube auto-generated translation. YouTube produces subtitle generated instantly and moving dynamically. A more noticeable link is Burgess and Green" ${ }^{[13]}$ term "YouTube's popular culture", within which all those who upload, view, comment on, or create content for YouTube are businesses, organizations, or private individuals, taking role as participants. In the sense of participatory system, YouTube allows users to contribute translation, opening chance for everyone to be involved within. Contribution is not limited in the form of translation as users' contribution can also be done through link embedding and sharing to increase view rate.

\section{Conclusion}

This paper points out that fansub and YouTube auto-generated subtitle signal fractional features of popular culture. Translation has long been practiced, evolved, and arrived at a point in which it fits some definitions of popular culture. As this research only studies a very small fragment of a broader picture, we propose, instead of conclude, the idea of "translation popular culture“. Further researches are encouraged to give more significant vision regarding the idea.

\section{References}

[1] Hatcher, J. S. Of Otaku and Fansubs: A Critical Look at Anime Online in Light of Current Issues in Copyright Law. SCRIPT-ed. 2005. 2(4) 514-542.

[2] Delaney, T. Pop culture: An overview. Philosophy Now: A Magazine of Ideas. 2007. $\begin{array}{llll}\text { Retrieved } \quad \text { May } & \text { 2020, from }\end{array}$ https://philosophynow.org/issues/64/Pop_Culture_An_Overview

[3] Popular Culture. (n.d.). Retrieved May 9, 2020, from https://www.oup.com.au/_data/assets/pdf_file/0020/58250/Chapter-13-Popularculture-obook-only.pdf 
[4] Karamitroglou, F.. A Proposed Set of Subtitling Standards in Europe. Translation Journal, 1998. 2(2).

[5] BBC Subtitle Guide Retrieved May, 92020 from https://bbc.github.io/subtitleguidelines

[6] Rong, L. Z. \& Omar, H. C. Understanding fansub as one of the audiovisual translation method. Kemanusiaan. 2018. 25(2). 109-127.

[7] Diaz-Cintas, J. 'Subtitling's a carnival': New practices in cyberspace. Jostrans. 2018. 30. 127-149.

[8] Lashley, M. C. Making Culture on YouTube: Case Studies of Cultural Production on the Popular Web Platform. Doctoral Thesis. University of Georgia. 2013.

[9] Kavoori, A. (2015). Making sense of YouTube. Global Media Journal. 2015. 13(24), $1-25$.

[10] https://support.google.com/youtube/answer/100078?co=GENIE.Platform\%3D Desktop\&hl=en

[11] https://support.google.com/youtube/answer/6373554?hl=en

[12] Jenkins, H. Convergence Culture: Where Old and New Media Collide. New York: New York University Press. 2006.

[13] Burgess, J. \& Green, J. YouTube: Online Video and Participatory Culture, Maiden, MA: Polity. 2009.

[14] Angelaki, V. High culture and/versus popular culture. Retrieved May 9, 2020 from https://uni-salzburg.at/fileadmin/oracle_file_imports/550475.PDF 